\title{
EVALUATION OF STUDENT'S PERCEPTION AND BEHAVIOR TOWARDS PLAGIARISM IN PAKISTANI UNIVERSITIES
}

\author{
Ghulam Murtaza, Seema Zafar, Iqra Bashir, Izhar Hussain ${ }^{1}$
}

\begin{abstract}
Background: The prevalence of academic delinquency in universities, predominantly in the form of plagiarism and cheating, is extensively conceded. Objectives: The objective of this study was to evaluate student's perception and behavior towards plagiarism in Pakistani universities. Methods: This cross-sectional survey was conducted in 6 academic disciplines in 35 universities in Pakistan during 21.02.2011-21.04.2011. Expert interviewers and learned educationists carried out the interviews with the help of a structured questionnaire to evaluate student's knowledge about plagiarism such as (i) student's knowledge about HEC policy, (ii) student's attitude towards plagiarism, (iii) student's satisfaction towards plagiarism and cheating, and (iv) their views for penalties (What should be the penalties for $1^{\text {st }}$ and $2^{\text {nd }}$ occurrence of plagiarism?) and recorded the responses. Results: This survey was accomplished by 25742 students. The response rate for awareness about HEC policy about plagiarism showed that significantly $(\mathrm{p}<0.05)$ low percentage $(94 \%)$ of students was unaware of this policy. The attitudes of significantly $(p<0.05)$ high percentage of students towards plagiarism behavior were unacceptable. Significantly $(p<0.05)$ high response rate towards attitudes regarding punishment for plagiarism was warning and report to HOD for first and second occurrence of this cheating, respectively. Conclusions: An extensive lack was found in the understanding of students towards plagiarism across all the universities. It is necessary to achieve balance between factors affecting plagiarism such avoidance, finding and sentence in case of detection.
\end{abstract}

Key words: pharmacy practice, academic honesty, plagiarism, cheating

\section{Evaluación de la percepción y el comportamiento de estudiantes hacia el plagio en las universidades paquistaníes}

Resumen: Antecedentes: La prevalencia de conductas éticas reprobables en las universidades, principalmente en la forma de plagio y engaño, es extensamente reconocida. Objetivos: Evaluar la percepción y comportamiento de los estudiantes hacia el plagio en las universidades paquistaníes. Métodos: Estudio transversal, que se llevó a cabo en seis disciplinas académicas en 35 universidades en Pakistán entre 21-02-2011 y 21-04-2011. Entrevistadores expertos y educadores eruditos llevaron a cabo las entrevistas con la ayuda de un cuestionario estructurado, para evaluar los conocimientos de los estudiantes sobre el plagio: en aspectos como (i) el conocimiento de los estudiantes acerca de la política HEC, (ii) la actitud del estudiante hacia el plagio, (iii) la satisfacción del estudiante hacia el plagio y el engańo, y (iv) sus puntos de vista en materia de sanciones (¿qué sanciones deberían aplicarse para la primera y segunda ocurrencia de plagio?). Se grabaron las respuestas. Resultados: La encuesta fue contestada por 25.742 estudiantes. La tasa de respuesta para la conciencia acerca de las políticas HEC sobre el plagio mostraron significativamente $(\mathrm{p}<0,05)$ bajo porcentaje $(94 \%)$. Los estudiantes no estaban al tanto de esta política. La actitud de rechazo al comportamiento de plagio muestra significativamente $(\mathrm{p}<0,05)$ un alto porcentaje. Los estudiantes consideraron que el plagio eran una conducta inaceptable. Significativamente $(\mathrm{p}<0,05)$ de alto índice fue la respuesta respecto de qué castigo se debería dar por plagio, la respuesta fue: advertencia e informar a HOD para la primera y segunda aparición de este engaño, respectivamente. Conclusiones: Se encontró una extensa falta de comprensión de los estudiantes hacia el plagio en todas las universidades. Es necesario, para alcanzar el equilibrio entre los factores que influencian el plagio, lograr detectar la evasión, buscando y sentenciando los casos encontrados.

Palabras clave: práctica farmacéutica, honestidad académica, plagio, engaño

Avaliaçáo da percepçáo e do comportamento de estudantes para o plágio nas universidades paquistanesas

Resumo: Antecedentes: A prevalência de condutas éticas reprováveis nas universidades, principalmente sob a forma de plágio e mentira, é extensamente reconhecida. Objetivos: Avaliar a percepção e o comportamento dos estudantes para o plágio nas universidades paquistanesas. Métodos: Este estudo transversal foi levado a cabo em seis disciplinas acadêmicas em 35 universidades no Paquistão de 21-02-2011 até 21-04-2011. Entrevistadores especialistas e educadores eruditos realizaram as entrevistas com a ajuda de um questionário estruturado, para avaliar os conhecimentos dos estudantes sobre o plágio: em aspectos como (i) o conhecimento dos estudantes acerca da política HEC, (ii) a atitude do estudante com relação ao plágio, (iii) a satisfação do estudante para com o plágio e a mentira, e (iv) seus pontos de vista em matéria de sançôes (que sançôes deveriam ser aplicadas para a primeira e segunda ocorrência de plágio?). Foram gravadas as respostas. Resultados: Esta enquete foi respondida por 25.742 estudantes. A taxa de resposta para a consciência acerca das políticas HEC sobre o plágio mostraram significativa $(\mathrm{p}<0,05)$ baixa porcentagem $(94 \%)$. Os estudantes não estavam a par desta política. A atitude de recusa ao comportamento do plágio mostra significativamente $(\mathrm{p}<0,05)$ uma alta porcentagem. Os estudantes consideraram que o plágio era uma conduta inaceitável. Significativamente $(\mathrm{p}<0,05)$ de alto índice foi a resposta a respeito do castigo que deveria ser dado ao plágio; a resposta foi: advertência e informar a HOD para o primeiro e segundo aparecimento deste engano, respectivamente. Conclusóes: Foi encontrada uma extensa falta de compreensão dos estudantes em relação ao plágio em todas as universidades. É necessário, para alcançar o equilibrio entre os fatores que influenciam o plágio lograr detectar a evasão, buscando e sentenciando os casos encontrados.

Palavras-chave: prática farmacêutica, honestidade acadêmica, plágio, engano

\footnotetext{
${ }^{1}$ Department of Pharmaceutical Sciences, COMSATS Institute of Information Technology, Abbottabad, Pakistan Correspondence: gmdogar356@gmail.com
} 


\section{Introduction}

The practice in which language of an author along with his thoughts being used by any person and representing them as an original work of one is termed as plagiarism(1). Before $18^{\text {th }}$ century, plagiarism was encouraged with a concept that "one can copy other author's work as much needed without any invention but now it is considered as immoral and unethical(2).

At university, students experience different behaviors and various levels of attitudes towards plagiarism. Their professional and learning abilities are proportional to their academic honesty. Academic honesty means "the work that has been submitted for the assessment of the student to award him credit to produce this work demonstrates the knowledge of the student and his understanding about this work" (3).

There is confusion in the understanding of the nature of plagiarism, as students and teachers do not look at the issue in same way and also the policy makers have their own understandings which creates gap between all three entities. It is possible that there is dissimilarity in the response that suites best for academic dishonesty by students(4).

In universities, dishonesty is the main reason of bad behavior and it is clear from the major studies carried out in different teaching institutes worldwide(5-13).

Academic delinquency appears to be prevalent in each and every discipline with little variations due to the differences in influencing factors such as type of assessment $\operatorname{task}(6)$. The disciplinary areas in which there is presence of carelessness in academic behavior, the reason is found to be lack of awareness(13). There are also other reasons such as work-load which cause academic dishonesty. In the results of some prototypes, there is indication that male students are more possible to detail cheating than female students. Men typically have lower levels of discipline making them more expected to cheat, and women have higher levels of predictable shame, making them less likely to give educational dishonesty(14).
In Pakistan, no published research has investigated the students' approaches and actions towards plagiarism. The aim of this study was to look at the attitudes of students towards various plagiarism methods, the response towards penalties and knowledge about anti-plagiarism policies. In this regards, an easy questionnaire was structured through which the response of students was observed and results were generated. The questions about the Higher Education Commission (HEC) policy for plagiarism were asked in such a way that the students had a choice to select one choice from the given options. This study also discussed the necessary actions to be taken so that the ratio of academic dishonesty might reduce reasonably.

\section{Methodology}

\section{Study design and study location}

This study was approved by the Departmental Review Committee of COMSATS Institute of Information Technology, Abbottabad, Pakistan. The administration of each university was contacted for getting permission to conduct the survey in the respective university. This cross-sectional survey was conducted in 6 academic disciplines in 35 government (universities that need economic support from government) and private (universities that produce their income themselves) universities in Pakistan during 21.02.201121.04.2011. The target population consisted of students enrolled in different departments such as pharmacy, engineering, humanities, management, agriculture and computer sciences. The minimum education prerequisite for inclusion in this study was 12 years education.

\section{Data collection}

The used sampling procedure was stratified random sampling. List of enrolled students, male and female, was acquired from each department. Students with non-serious nature were excluded from the study. A computer generated simple random sample of students was choosed. The selected students were interviewed in their respective class rooms. Expert interviewers and learned edu- 
cationists carried out the interviews with the help of a structured questionnaire to evaluate student's knowledge about plagiarism such as (i) student's knowledge about HEC policy, (ii) student's attitude towards plagiarism, (iii) student's satisfaction towards plagiarism and cheating, and (iv) their views for penalties (What should be the penalties for $1^{\text {st }}$ and $2^{\text {nd }}$ occurrence of plagiarism?) and recorded the responses. Overall, it consumed approximately $25 \mathrm{~min}$ (shortest possible time) per student for complete interview. In case of absence of a selected student, second attempt was made to take his/her interview. After the completion of survey in each department, the booklets containing information about plagiarism were given out to the students.

The response rate in this study was $92.28 \%$ that supports the fact that such a high number of students had curiosity of learning more about plagiarism. The knowledge assessment tool consisting of various questions is reported in Table $1-3$. The contents of questionnaire were validated (15) by expert opinion of an educationist having extensive experience in education. The questionnaire consisted of following types of questions: (i) dichotomous questions (Yes/No), (ii) multiplechoice questions $(\mathrm{a} / \mathrm{b} / \mathrm{c})$, and (iii) short questions for explanation.

\section{Data analysis}

The obtained data was analyzed using SPSS version 13.0.

\section{Results}

This survey was accomplished by 25742 students from 6 departments of 35 different universities. The awareness of students about HEC policy about plagiarism was significantly $(\mathrm{p}<0.05)$ poor i.e. $94 \%$ students were unaware of this policy (Figure 1). The attitudes of significantly high $(\mathrm{p}<0.05)$ percentage of students towards plagiarism behavior were unacceptable (Table 1). Significantly $(\mathrm{p}<0.05)$ high response rate towards attitudes regarding punishment for plagiarism was warning and report to HOD for first and second occurrence of this cheating, respectively.

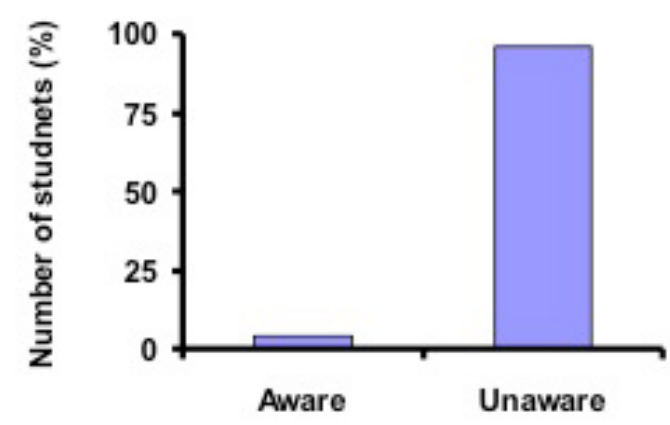

Figure 1. Response rate for awareness about HEC policy about plagiarism

Significantly $(\mathrm{p}<0.05)$ lesser number $(27.6 \%)$ of university students responded that plagiarism is acceptable (Table 1).

\begin{tabular}{|c|c|c|c|}
\hline No. & Strategy & Acceptable (\%) & Unacceptable (\%) \\
\hline 1 & $\begin{array}{l}\text { To discuss } \\
\text { assignment with } \\
\text { your friends and let } \\
\text { him copy. }\end{array}$ & $7120(27.6 \%)$ & $17920(69.6 \%)$ \\
\hline 2 & $\begin{array}{l}\text { Not to contribute } \\
\text { in group } \\
\text { assignment }\end{array}$ & $8650(33.6 \%)$ & $17200(66.8 \%)$ \\
\hline 3 & $\begin{array}{l}\text { Copying } \\
\text { another student's } \\
\text { assignment with } \\
\text { and without their } \\
\text { permission }\end{array}$ & $11030(42.8 \%)$ & $13790(54.3 \%)$ \\
\hline 4 & $\begin{array}{l}\text { Collecting required } \\
\text { material from } \\
\text { different sources } \& \\
\text { combine it to make } \\
\text { an assignment }\end{array}$ & $18040(70.0 \%)$ & $780(3.0 \%)$ \\
\hline 5 & $\begin{array}{l}\text { Asking your friends } \\
\text { to make your } \\
\text { assignment }\end{array}$ & $8980(34.8 \%)$ & $16900(65.6 \%)$ \\
\hline 6 & $\begin{array}{l}\text { Submitting } \\
\text { assignment of your } \\
\text { senior student } \\
\text { who made it in } \\
\text { respective semester }\end{array}$ & $7120(27.6 \%)$ & $18750(72.8 \%)$ \\
\hline
\end{tabular}

Table 1. Attitudes of students towards plagiarism 
Evaluation of student's perception and behavior towards plagiarism in Pakistani universities - Ghulam Murtaza et al.

Table 2 shows the frequencies of the students who responded towards penalties in a case when plagiarism is detected. Most (55.6\%) of the university students were in favor of warning and canceling of assignment as a punishment for first time detection/occurrence. Almost one third of the students were of the view that resubmission of assignment will be a better option or the assessment should be undertaken in some other way. In case of second time detection, most $(48 \%)$ of the students preferred to report the HOD while fewer $(6 \%)$ were of the view to cancel the assignment with zero marks as they care about their friends and they were of the view that there will be a valid reason behind cheating. Other frequencies are shown in the Table 3 in this regards. We gained these findings from the written comments of students to make their answers reasonable. Students who were ready to report to HOD, were of the view that plagiarism gives benefits to those students who do not deserve. The students who were found not ready to report such act, were of the view that this does not matter to them and it is not their responsibility to catch such students, rather teaching staff should take this into their account. The overall behaviors about preparing and submitting an assignment in time is given in Table 3.

\begin{tabular}{|l|l|l|}
\hline \multicolumn{2}{|l|}{ First occurrence } \\
\hline No. & Penalties & $\begin{array}{l}\text { First } \\
\text { occurrence }\end{array}$ \\
\hline 1 & No action & $14 \%$ \\
\hline 2 & Warning & $55.6 \%$ \\
\hline 3 & Cancel that assignment & $16 \%$ \\
\hline 4 & Report to HOD & $6 \%$ \\
\hline Second occurrence & $48 \%$ \\
\hline 1 & Report to HOD & $6 \%$ \\
\hline 2 & $\begin{array}{l}\text { Student should be declared as } \\
\text { fail in that subject }\end{array}$ & $18 \%$ \\
\hline 3 & Student should be demoted & $7.6 \%$ \\
\hline 4 & Student should be expelled & \\
\hline
\end{tabular}

Table 2. Attitudes of students towards penalties

\begin{tabular}{|c|c|c|c|c|}
\hline No. & Strategy & Agree & Disagree & No opinion \\
\hline 1 & $\begin{array}{l}\text { Short deadline } \\
\text { to submit } \\
\text { assignment is } \\
\text { root cause of } \\
\text { plagiarism. }\end{array}$ & $\begin{array}{l}16780 \\
(65 \%)\end{array}$ & $\begin{array}{l}4640 \\
(18 \%)\end{array}$ & $\begin{array}{l}4240 \\
(16.4 \%)\end{array}$ \\
\hline 2 & $\begin{array}{l}\text { Those who say } \\
\text { that they have } \\
\text { never copied from } \\
\text { anywhere are } \\
\text { lying. }\end{array}$ & $\begin{array}{l}16900 \\
(65.6 \%)\end{array}$ & $\begin{array}{l}4860 \\
(18.8 \%)\end{array}$ & $\begin{array}{l}4020 \\
(15.6 \%)\end{array}$ \\
\hline 3 & $\begin{array}{l}\text { Sometimes it } \\
\text { is necessary to } \\
\text { plagiarize (if you } \\
\text { have another } \\
\text { important task } \\
\text { to do you can } \\
\text { plagiarize) }\end{array}$ & $\begin{array}{l}16700 \\
(64.8 \%)\end{array}$ & $\begin{array}{l}5380 \\
(20.8 \%)\end{array}$ & $\begin{array}{l}3720 \\
(14.4 \%)\end{array}$ \\
\hline 4 & $\begin{array}{l}\text { Plagiarizing is as } \\
\text { bad as to steal } \\
\text { from someone. }\end{array}$ & $\begin{array}{l}13500 \\
(52.4 \%)\end{array}$ & $\begin{array}{l}7940 \\
(30.8 \%)\end{array}$ & $\begin{array}{l}4340 \\
(16.8 \%)\end{array}$ \\
\hline 5 & $\begin{array}{l}\text { If your fellow } \\
\text { student let you } \\
\text { copy, you are } \\
\text { doing nothing } \\
\text { bad. }\end{array}$ & $\begin{array}{l}15560 \\
(60.4 \%)\end{array}$ & $\begin{array}{l}6800 \\
(26.4 \%)\end{array}$ & $\begin{array}{l}3410 \\
(13.2 \%)\end{array}$ \\
\hline
\end{tabular}

Table 3. Behaviors about preparing and submitting an assignment in time

\section{Discussion}

In the survey, we found the responses of university students about: (i) knowledge of students, (ii) their attitudes towards plagiarism, and (iii) response about penalties. The results for almost all degree programs/departments show that majority of students were unaware of HEC policy about plagiarism and few knew about policies and penalties for plagiarism.

The knowledge of students about HEC policies does not mean that they know about the existence of a policy, but the knowledge that a policy covers what aspects about academics. Sensible awareness is the basic theme of knowledge about a policy. It is the responsibility of teachers and administration to take such steps that the students not only know about the existence of HEC policy, they should have understanding about its contents.

The state of these Pakistani students in regards of plagiarism is alarming. The principles about academics which should be acceptable to the stu- 
dents, were rejected by the students and vice versa. Majority of students are always ready to adopt inappropriate way and so they are at risk of punishment in the form of plagiarism penalty. In case of plagiarism detection there was an unreasonable perception of the students. They have a view that plagiarism is not that much bad and it must not end with penalties. Though plagiarism is widely spread, yet the results of this survey are likely to be a surprise for majority of readers.

From the dawn of internet, plagiarism has become very easy task for the students to download the desired data for their assignments and copy it through one click only. Another cause towards academic dishonesty is the increased size of classes which results the submission of grouped assignments. This creates lack of contact because many students in this phenomenon do not perform their task of assignments and put the burden on others. This causes negative affect on moral behavior and academic misbehavior. Following actions may be useful to achieve better results: (i) proper education of students about policy and unexpected penalties, (ii) scheming to support the students for their learning to reduce plagiarism, and (iii) procedures to observe and detect cheating with suitable punishment.

The rate at which the students plagiarize and cheat is determined in this study which shows that most infringements occur in coursework situations. On student's side, they have a view that it is good to use referencing principle for understanding process and in their written work use of source material is a successful policy. Here, a clear gap is found between their knowledge and the use of facilities to complete their work. The results raise many questions about the awareness of students for plagiarism, and whether such behavior has any justification in their degree programs.

Students are likely to cheat because they need to submit their work in defined time. Another cause of academic dishonesty is the grade point average (GPA) of students. Studies(11-13) have shown that some of the students cheat for high academic record in order of GPA while some others cheat because they need to increase their GPA which is going low.

A study involving self-reported plagiarism and cheating attitudes in four Australian universities has been reported in literature that exhibited no linkage between the prevalence of plagiarism and dishonesty and the stipulation of information on academic honesty guidelines to the students(6). In another study, it has been found that first-year undergraduate science and engineering cohorts in Australia were probably bonded with the prevalence of conspiracy and devious activities(3). Academic misconduct in students planning careers in business, science, engineering and technology in various academic institutes in USA has also been reported(9-11). In United Kingdom, the incidence of plagiarism and dishonest behaviors in coursework situations has been observed in pharmacy undergraduates, with a finding that most infringements occurred(12). In Canada also, high prevalence of pharmacy student's self-reported use of dishonest behaviors has been narrated(13).

The factors of teaching methodology have also an impact on cheating behavior of students. Teachers must never compromise on justice and never go personal with any student. They must focus on learning process of students and improve their understanding. This really plays a vital role in developing the honest behavior of student's for their academics.

\section{Conclusion}

An extensive lack was found in the understanding of students towards plagiarism across all the universities. It is necessary to achieve balance between factors affecting plagiarism such avoidance, finding and sentence in case of detection. Moreover, the real causes behind plagiarism need to be determined through researches and interference strategies are to be developed so that plagiarism could be well handled. 
Evaluation of student's perception and behavior towards plagiarism in Pakistani universities - Ghulam Murtaza et al.

\section{References}

1. De Lambert K, Ellen N, Taylor L. Chalkface challenges: a study of academic dishonesty amongst students in New Zealand tertiary institutions. Assess Eval Higher Educ 2006; 31(5): 485-503.

2. Yeo S. First-year university science and engineering students' understanding of plagiarism. Higher Educ Res Dev 2007; 26(2): 199-216.

3. McCabe D. It takes a village: academic dishonesty and educational opportunity. Libr Educ 2005; 91(3): 26-31.

4. Ryan G, Bonanno H, Krass I, Scouller K, Smith L. Undergraduate and postgraduate pharmacy students' perceptions of plagiarism and academic honesty. American Journal of Pharmaceutical Education 2009; 73(6): 1-8.

5. Ashworth P, Bannister P, Thorne P. Guilty in whose eyes? University students' perceptions of cheating and plagiarism in academic work and assessment. Stud Higher Educ 1997; 22(2): 187-203.

6. Marsden H, Carroll M, Neill JT. Who cheats at university?: A self-report study of dishonest academic behaviors in a sample of Australian university students. Aust J Psychol 2005; 57(1): 1-10.

7. Jocoy C, Di Biase D. Plagiarism by adult learners online: a case study in detection and remediation. Int Rev Res Open Distance Learn 2006; 7(1): 1-15.

8. Kerkvliet J, Sigmund CL. Can we control cheating in the classroom? J Econ Educ 1999; Fall: 331-343.

9. McCabe DL, Trevino LK. Cheating among business students: a challenge for business leaders and educators. J Manag Educ 1995; 19(2): 205-218.

10. Newstead S, Franklin-Stokes A, Armstead P. Individual differences in student cheating. J Educ Psychol 1996; 88(2): 229-241.

11. McCullough M, Holmberg M. Using the Google search engine to detect word-for-word plagiarism in master's theses: a preliminary study. Coll Student J 2005; 39(3): 435-441.

12. Aggarwal R, Bates I., Davies JG, et al. A study of academic dishonesty among students at two pharmacy schools. Pharm J 2002; 269(7219): 529-533.

13. Austin Z, Collins D, Remillard A, et al. Influence of attitudes toward curriculum on dishonest academic behavior. Am J Pharm Educ 2006; 70(3): 50.

14. Hardigan PC. First- and third-year Pharmacy students' attitudes toward cheating behaviors. Am J Pharm Educ 2004; 68(5): Article 110.

15. Streiner DL, Norman GR: Devising the Items. In: Health Measurement Scales. New York, Oxford University Press Inc.; 2002: 15-127.

Received: August 16, 2011

Accepted: October 2, 2011 